\title{
ANALYZING SERVICE FAILURES WHEN SHOPPING FOR SUPPLEMENTS ONLINE AMONG COLLEGE STUDENTS
}

\author{
Thomas O. Uitz* \\ Eva Jančiková**
}

Received: 5. 1. 2021

Preliminary communication

Accepted: 16. 12. 2021

UDC 658.818:004.738.5

DOI https://doi.org/10.30924/mjcmi.27.1.2

\begin{abstract}
This article analyses customer dissatresponse to a service failure and customer isfaction and service recovery methods in purchasing sports nutrition and supplements online. The data were collected using an online survey in which 155 students from eight Central and Eastern European (CEE) countries participated. The study analyzed the data using the Mann-Whitney $U$ test and the chi-square test. There was a positive relationship between online retailers'

\section{INTRODUCTION}

With the increase in the coronavirus pandemic (COVID-19), the demand for vitamins and supplements is also increasing because it is believed that vitamins can help prevent the disease. The increase in sedentary lifestyle is one of the main reasons for taking supplements, as they can alleviate the problems caused by such a lifestyle and loyalty. More than $41 \%$ of respondents felt more loyal to the online retailer after successfully dealing with a service failure. In addition, about $60 \%$ of respondents were willing to buy again and recommend the online retailer to other consumers.

Keywords: marketing, retail, service failure, service marketing

poor eating habits (Anzivino \& Moliterno, 2020).

University students are more likely to purchase dietary supplements than any other group in the general population because they desire to boost their energy, muscle, and overall health. As a result, university students spend a significant portion of their budget on dietary supplements, and $66 \%$

\footnotetext{
* Thomas O. Uitz, MBA, Faculty of International Relations, University of Economics in Bratislava, Dolnozemská cesta 1/b, 85235 Bratislava, Slovak Republic, E-mail: thomas.uitz@gmx.at, ORCID: https://orcid.org/00000002-5843-0383

** Prof. Dr. Habil. Eva Jančíková, PhD, Faculty of International Relations, University of Economics in Bratislava, Dolnozemská cesta 1/b, 85235 Bratislava, Slovak Republic, E-mail: eva.jancikova@euba.sk, ORCID: https:// orcid.org/0000-0003-1328-6872
} 


\section{Journal of Contemporary Management Issues}

use them at least once a week (Daniells, 2015).

So, like all other businesses, dietary supplement manufacturers need a competitive edge to succeed in the industry. However, one of the areas where greater effectiveness can be achieved is post-purchase management, particularly complaint handling. Improving complaint handling is critical for all companies, as service failures occur in all business processes.

Uitz \& Jancikova (2021) addressed the role of word of mouth in handling service failures related to online purchasing.

One of the under-researched areas in dealing with service failures is students' reaction to (online) service failures in terms of follow-up. The purpose of this study was to understand and explain the response of students from CEE who encountered a problem when selecting sports nutrition and supplements online. However, brick and mortar stores are not included in this study. The following research questions were developed to explore the topic:

- How often has a service failure occurred?

- Who has experienced a service failure?

- What type of service failure has occurred?

\section{LITERATURE REVIEW AND HYPOTHESES DEVELOPMENT}

Service failures can occur for various reasons (Forbes et al., 2005). Social media platforms such as Facebook and Twitter make it easy for disgruntled customers to spread negative word of mouth (Larivière et al., 2013).
Dietary supplements are purchased more frequently by university students than any other population group. The main goals are to increase energy, muscle mass, and overall health. Although dietary supplements are costly for university students, $66 \%$ take them at least once a week (Daniells, 2015).

Consequently, most companies have recognized the need to provide excellent customer service because even the best companies make mistakes in service delivery. This situation is referred to as service failure. Service failures include core service failures, product and policy failures, and customer service failures (Komunda \& Osarenkhoe, 2012).

According to Kuo and $\mathrm{Wu}$ (2012), increased customer satisfaction after a service recovery is a good predictor of repurchase intention in an online environment. Chang et al. (2012) found a relationship between the reason for repurchase and service recovery in online services. Customers may still be disappointed, but they prefer to buy from a known company (Komunda \& Osarenkhoe, 2012).

Lin and Lekhawipat (2014) found that satisfied customers are more likely to return to the same shop in the future than dissatisfied customers. According to Ozturk et al. (2016), perceived convenience significantly impacts repurchase expectations. Perceived trust is another critical component in the online market and one of the driving forces behind online purchases (Toufaily et al., 2013).

Six hypotheses were developed and tested to investigate the services online stores could create. The hypotheses were developed around the ideas of administrative disappointment and administrative recovery. The goal of this research was to understand 
online help disappointment. Information on socio-demographic characteristics, general data, and other elements that might affect online help disappointments and customer satisfaction are analyzed. The hypotheses are related to customer loyalty $(\mathrm{H} 1-\mathrm{H} 3)$ and purchase intention (H4-H6):

H1: Customers feel more loyal to an online retailer after experiencing the company's response.

This hypothesis aims to confirm the positive influence of a retailer's response and the level of loyalty. This is an essential factor in evaluating the importance of the initial response.

H2: Customers feel more loyal to a retailer after experiencing a positive service recovery.

This hypothesis focuses on the different levels of loyalty and service recovery instruments and tests whether the service recovery paradox holds.

H3: Customers feel more loyal to an online retailer after experiencing the company's significant efforts.

This hypothesis evaluates the company's efforts to get more loyal customers.

H4: If the online retailer does not respond to a complaint, customers are less likely to repurchase from it.

This hypothesis focuses on the relationship between the company's response and customers buying from that retailer again, which is also critical for customer loyalty.

H5: Dissatisfied customers are less likely to repurchase from the same online retailer.

This hypothesis focuses on the differences between levels of repeat purchase.
H6: Customers are less likely to repurchase from the same online retailer showing no/less effort.

This hypothesis focuses on the extent to which customers and shoppers make an effort to buy again from that retailer.

The relationship between repurchase intent and satisfaction is substantial, especially with a high purchase frequency (Chang et al., 2012). Therefore, online retailers should consistently review grumbling discussions and respond as quickly as possible or offer customers an input component to keep them on the site rather than complaining elsewhere (Goetzinger et al., 2006).

Van Vaerenbergh et al. (2013) noted that research does not always include additional customers in service recovery efforts. Customers' behaviors and interactions may change when they witness service recovery experienced by other customers.

As Mangold and Smith (2012) show, customers can influence the purchasing decisions of numerous individuals within seconds by using the Internet. Therefore, responding to the growing number of online objections should be firmly established by adopting courses of action, applying adequate strategies, and using web-based media. Even though individuals use telephone, mail, and face-to-face contact to complain, web-based media offer people another medium to anonymously communicate their views and feelings (Tripp \& Grégoire, 2011).

\section{METHODS}

This is an exploratory study, given a small number of studies on service failures in online purchases of dietary supplements or sports nutrition products. The study used 


\section{Journal of Contemporary Management Issues}

a 24-question, five-part questionnaire based on the author's own experience and interviews with managers from Austria's leading online sports nutrition stores. The collaborative and research-participatory method was used (Sahu, 2016). Other data collection methods were considered, such as face-to-face interviews with shoppers and online retailers. However, a web-based survey proved to be the best option due to the lockdown and uncertain scenario associated with the COVID-19 pandemic. The questionnaire was simultaneously administered to eight higher education institutions in CEE between May and August 2020 using a web-based tool (LimeSurvey). Data were analyzed using the software package IBM SPSS 23.

\section{RESULTS}

Two hundred and eighty-seven individuals accessed the online survey, and 155 participants completed the questionnaire. Of the given number, 122 participants reported a service failure when purchasing online. Only the participants who experienced a service failure were included in the analysis. Of the participants, 69 were men and 51 were women, and two did not complete the questionnaire.

Approximately $79 \%$ of respondents had experienced a service failure at least once since January 1, 2020, and $21 \%$ had no complaints when purchasing supplements and sports nutrition online.

Individuals who were disappointed with the assistance tended to be younger. In contrast, those dissatisfied with the administration had more established exceptions. There is also strong evidence of a relationship between the device used and experiencing a service disappointment: $2(1, \mathrm{~N}=155)$ $=7.42, \mathrm{p}<.006$. Individuals who ordered with a PC /notebook had significantly fewer service failures than individuals who used a tablet or cell phone.

One-third of respondents experienced a process failure (e.g., the order was not delivered or the wrong product was delivered), and $20 \%$ experienced technical problems, such as the website not working. Poor payment methods (e.g., no bank transfer or no PayPal) accounted for $13 \%$ of the issues.

Hypothesis testing is used to determine the plausibility of hypotheses based on sample data. The test provides evidence and details to accept or reject the hypothesis.

H1: Customers feel more loyal to an online retailer after experiencing the company's response.

The chi-square test of association $(2 \times 2)$ shows a strong relationship between company response (yes) and more loyal shoppers: $2(1, \mathrm{~N}=93)=10.02, \mathrm{p}<.002$. About $11.8 \%$ of companies did not respond to complaining customers.

As shown in Figure 1, more than $90 \%$ of these customers felt less loyal after the service recovery. In general, a response is essential, but failure to respond has a negative impact. Customers demand to be responded to, and companies are expected to do so - otherwise, the level of loyalty suffers. The hypothesis is confirmed: People feel significantly more connected to the online retailer if the retailer (at least) responds to complaints. 


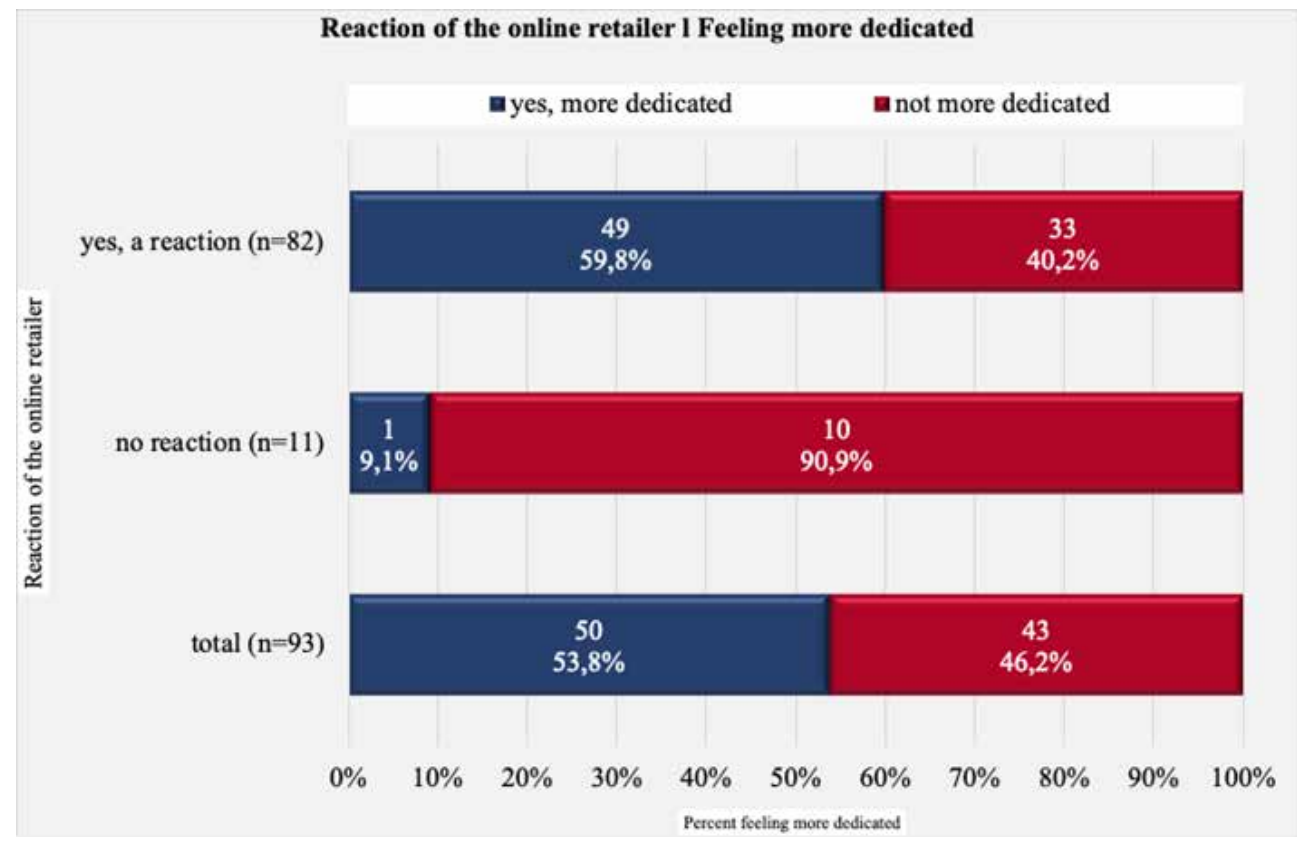

Figure 1. Reaction of the online retailer

H2: Customers feel more loyal to an online retailer after experiencing a positive service recovery.

The two-tailed Mann-Whitney U test was conducted to examine significant differences between the level of loyalty and the different aspects of service recovery. The result of the test is significant, as shown in Table 1. 
Table 1. Mann-Whitney-U Test

\begin{tabular}{|c|c|c|c|c|}
\hline & $\begin{array}{l}\text { Asym. sig. } \\
\text { (2-sided) }\end{array}$ & $\mathbf{Z}$ & Wilcoxon-W & $\begin{array}{c}\text { Mann- } \\
\text { Whitney U }\end{array}$ \\
\hline $\begin{array}{l}\text { Satisfaction with the } \\
\text { solution }\end{array}$ & .000 & -7.666 & 1396.000 & 121.000 \\
\hline Sincere apology & .000 & -5.741 & 1488.000 & 263.000 \\
\hline $\begin{array}{l}\text { Solution for } \\
\text { the problem }\end{array}$ & .000 & -6.879 & 1455.000 & 180.000 \\
\hline $\begin{array}{l}\text { Courtesy of the service } \\
\text { provider }\end{array}$ & .000 & & & \\
\hline $\begin{array}{l}\text { Explanation of the } \\
\text { failure }\end{array}$ & .000 & & & \\
\hline $\begin{array}{l}\text { Quick } \\
\text { response }\end{array}$ & .000 & -5.790 & 1552.000 & 277.000 \\
\hline $\begin{array}{l}\text { Appropriate compen- } \\
\text { sation }\end{array}$ & .000 & -6.431 & 1431.500 & 206.500 \\
\hline $\begin{array}{l}\text { Offering professional } \\
\text { support }\end{array}$ & .000 & -4.722 & 1164.500 & 261.500 \\
\hline Effort of the company & .000 & -6.038 & 1492.500 & 217.500 \\
\hline $\begin{array}{l}\text { Follow-up after the } \\
\text { recovery }\end{array}$ & .000 & -4.986 & 487.000 & 81.000 \\
\hline $\begin{array}{l}\text { Efficient, fast avail- } \\
\text { ability }\end{array}$ & .000 & -6.651 & 1428.500 & 153.500 \\
\hline $\begin{array}{l}\text { Personal contact } \\
\text { through call }\end{array}$ & .000 & -5.084 & 643.500 & 82.500 \\
\hline
\end{tabular}

Note: Grouping variable - more dedicated. 
The hypothesis is confirmed: individuals feel significantly more loyal to an online retailer who (at least) responds. Satisfaction with the offered solution and a sincere apology offer the best result in terms of loyalty. Offering professional support and efficient and fast availability recorded the lowest scores, as shown in Figure 2.

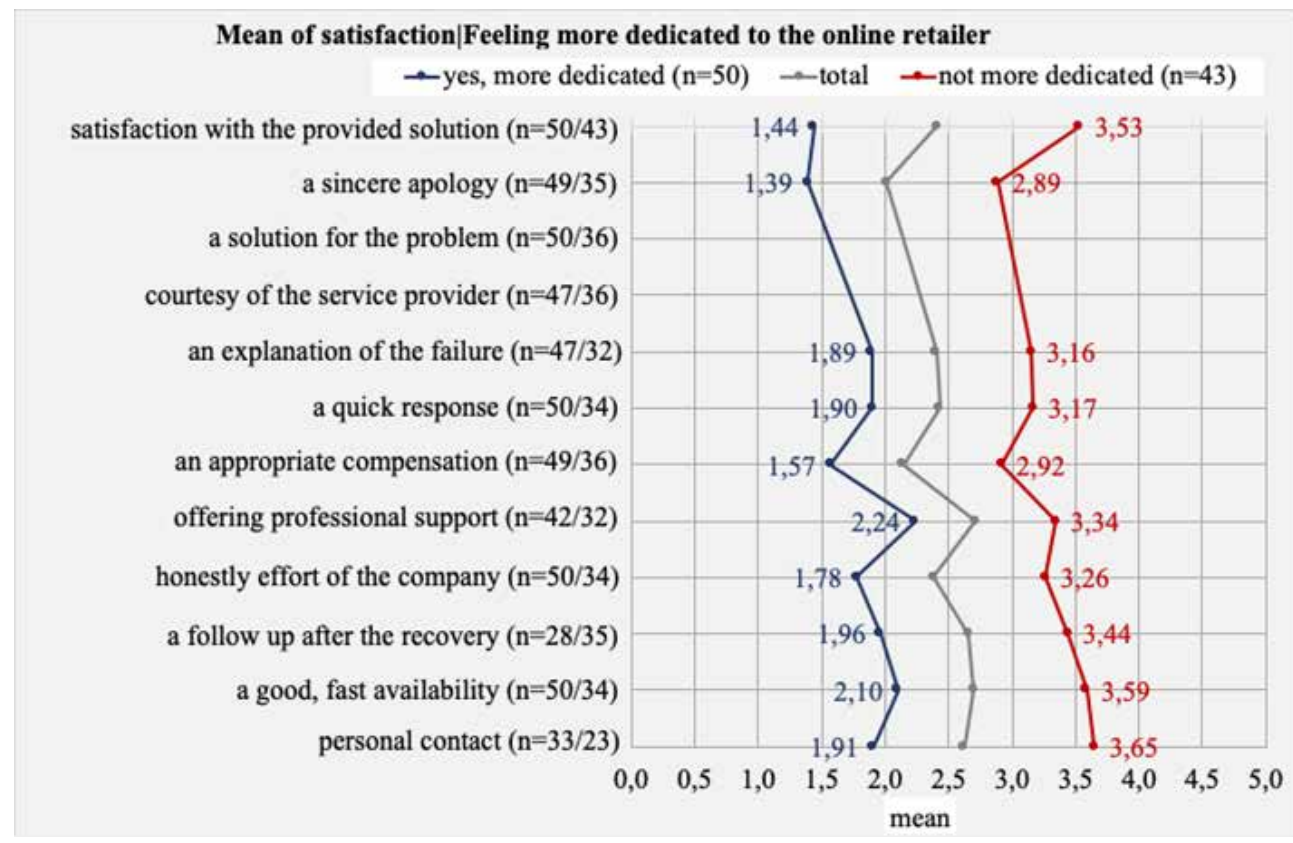

Figure 2. Mean of satisfaction

Customers are extremely "strict" with online retailers. When they are completely satisfied, they feel more attracted to the merchant.

H3: Customers feel more loyal to an online retailer after experiencing the company's significant efforts.

First, the chi-square test of association $(2 \times 2)$ shows the relationship between a high level of effort by the company and more loyal buyers: $2(1, \mathrm{~N}=93)=47.12$, $\mathrm{p}<.000$. Customers who experienced a high level of effort by the company during recovery rewarded them with more loyalty, suggesting that customers respond to companies that show effort and initiative during this process.
There is a negative relationship between the levels of buyer effort and loyalty: 2 (2, $\mathrm{N}=93)=13.55, \mathrm{p}<.001$. Therefore, buyers who take care of themselves and show extremely high involvement and effort are less loyal to the company.

Third, the evidence of the relationship between these variables is extremely strong: $2(1, \mathrm{~N}=93)=61.42, \mathrm{p}<.000$. Customers feel more loyal when their effort is lower than the company's effort. This is an important conclusion from the study: the company's effort must be higher than the customers' effort to have more loyal customers.

Individuals who experienced a high level of effort by the online retailer feel significantly more loyal. Confirming the hypothesis: People feel substantially more 


\section{Journal of Contemporary Management Issues}

connected to an online retailer after experiencing the company's great effort in providing services.

H4: If the online retailer does not react to a complaint, customers are less likely to repurchase from it.

The chi-square test of association $(2 \times 2)$ shows the relationship between a company's response and shoppers buying from that company again: $2(1, \mathrm{~N}=95)=19.22, \mathrm{p}<$ .000 . Seventy-five percent of respondents who received a company response will buy again - no response results in $90.9 \%$ of customers considering not buying from that retailer again. As explained in $\mathrm{H} 1$, no response harms customer behavior. Therefore, the customers whose complaints were responded to by the Internet retailer are bound to buy from that retailer again. The hypothesis is confirmed: Customers are significantly less likely to buy from the selected retailer if the company does not respond to the complaint, as shown in Figure 3.

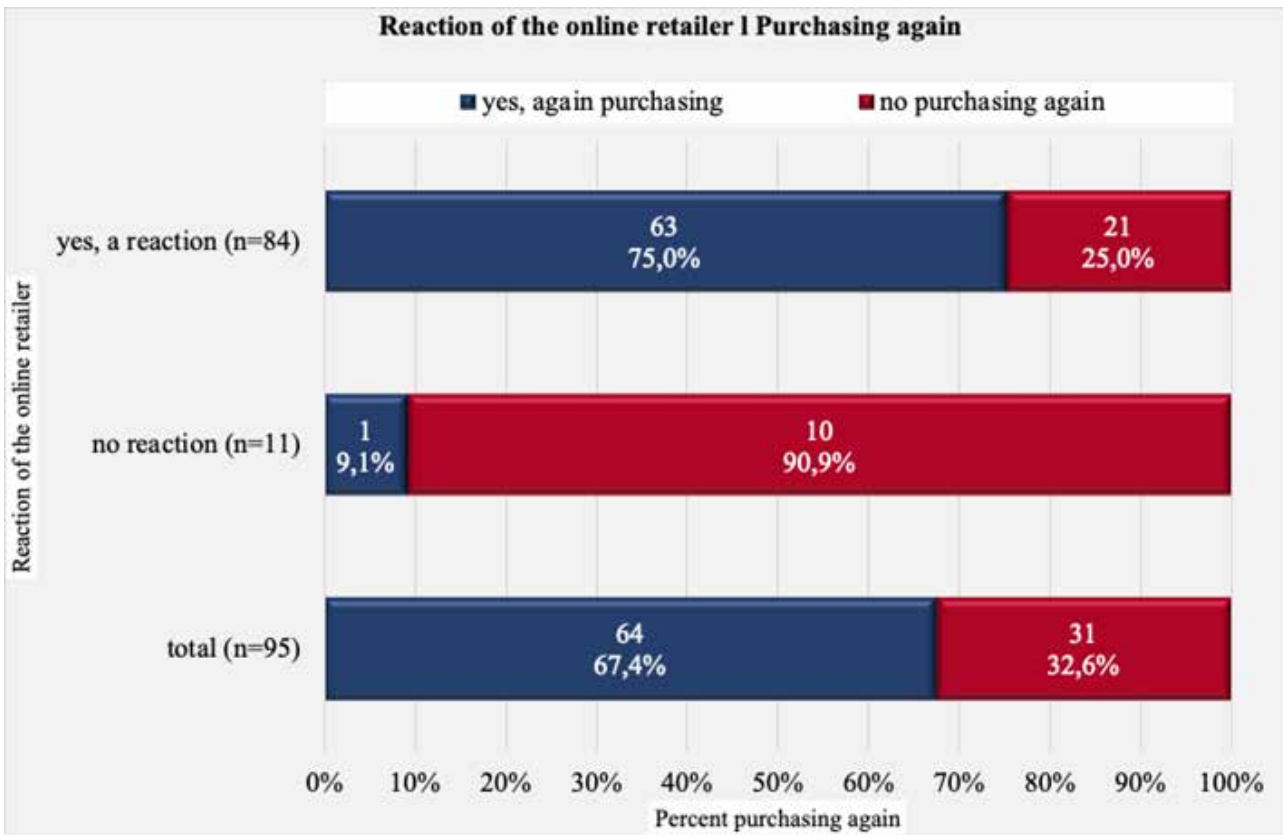

Figure 3. Reaction of the online retailer

H5: Dissatisfied customers are less likely to repurchase from the same online retailer.

The two-tailed Mann-Whitney U test examined the significant differences between repurchase and service restoration. Table 2 shows that the result of the twotailed Mann-Whitney U test was significant. 
Table 2. Mann-Whitney-U test

\begin{tabular}{|c|c|c|c|c|}
\hline & $\begin{array}{l}\text { Asym. sig. } \\
\text { (2-sided) }\end{array}$ & $\mathbf{Z}$ & Wilcoxon-W & $\begin{array}{c}\text { Mann- } \\
\text { Whitney-U }\end{array}$ \\
\hline $\begin{array}{l}\text { Satisfaction with the provided } \\
\text { solution }\end{array}$ & .000 & -7.556 & 2161.500 & 81.50 \\
\hline Sat. [sincere apology] & .000 & -5.686 & 2141.500 & 188.50 \\
\hline Sat. [solution for the problem] & .000 & -6.938 & 2170.000 & 90.00 \\
\hline $\begin{array}{l}\text { Sat. [courtesy of the service } \\
\text { provider] }\end{array}$ & .000 & -5.906 & 2048.500 & 157.50 \\
\hline Sat. [explanation of the failure] & .000 & -4.580 & 2118.500 & 22.50 \\
\hline $\begin{array}{l}\text { Sat. [quick response to my } \\
\text { questions and my failure] }\end{array}$ & .000 & -5.506 & 2293.000 & 213.00 \\
\hline Sat. [appropriate compensation] & .000 & -5.826 & 2202.500 & 187.50 \\
\hline $\begin{array}{l}\text { Sat. [offering professional } \\
\text { support] }\end{array}$ & .000 & -5.188 & 1801.500 & 148.50 \\
\hline $\begin{array}{l}\text { Sat. [effort of the company to } \\
\text { solve my issue] }\end{array}$ & .000 & -6.045 & 2133.500 & 117.50 \\
\hline $\begin{array}{l}\text { Sat. [follow-up after the problem } \\
\text { was solved] }\end{array}$ & .000 & -4.427 & 916.000 & 96.00 \\
\hline $\begin{array}{l}\text { Sat. [efficient and fast availability } \\
\text { of the company] }\end{array}$ & .000 & -5.933 & 2144.500 & 128.50 \\
\hline Sat. [personal contact by call] & .000 & -4.611 & 947.000 & 86.00 \\
\hline
\end{tabular}

Note: Grouping variable - repurchasing. 


\section{Journal of Contemporary Management Issues}

The hypothesis is confirmed: Customers who are satisfied with the recovery purchase significantly more often than customers who are only moderately satisfied.
Therefore, solving the problem and a sincere apology are the two top scores, as shown in Figure 4.

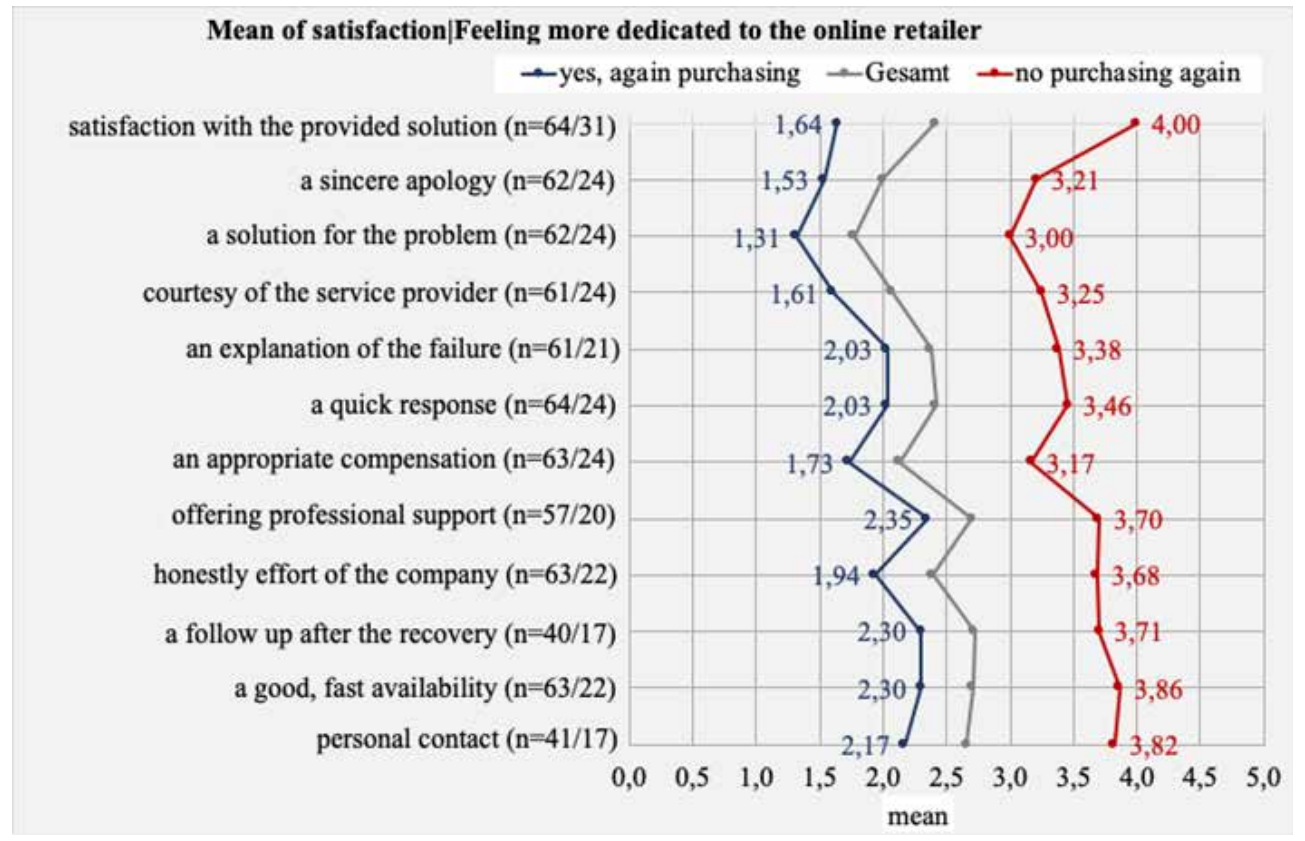

Figure 4. Mean of satisfaction

H6: Customers are less likely to repurchase from the same online retailer that showed no/less effort.

The chi-square test of association (2x2) shows the following results. First, there is evidence of a relationship between a company's (very) high effort and shoppers who buy from that retailer again $-2(2, \mathrm{~N}=94)$ $=43.10, \mathrm{p}<.000$. All customers want to repurchase from a retailer that puts significant effort into the service recovery.

However, there is evidence of a relationship between a (very) high level of customer effort and not wanting to buy again from that retailer: $2(1, \mathrm{~N}=94)=$ $37.95, \mathrm{p}<.000$. If the customer puts in a high level of effort, the willingness to buy again drops fundamentally.

Online retailers must show a high level of effort in solving the problem to get a higher purchase rate. Customers turn away from merchants who take (almost) no action. The hypothesis is confirmed: Customers are significantly less likely to purchase from a retailer if the company makes less or no effort to solve the problem, as shown in Figure 5. 


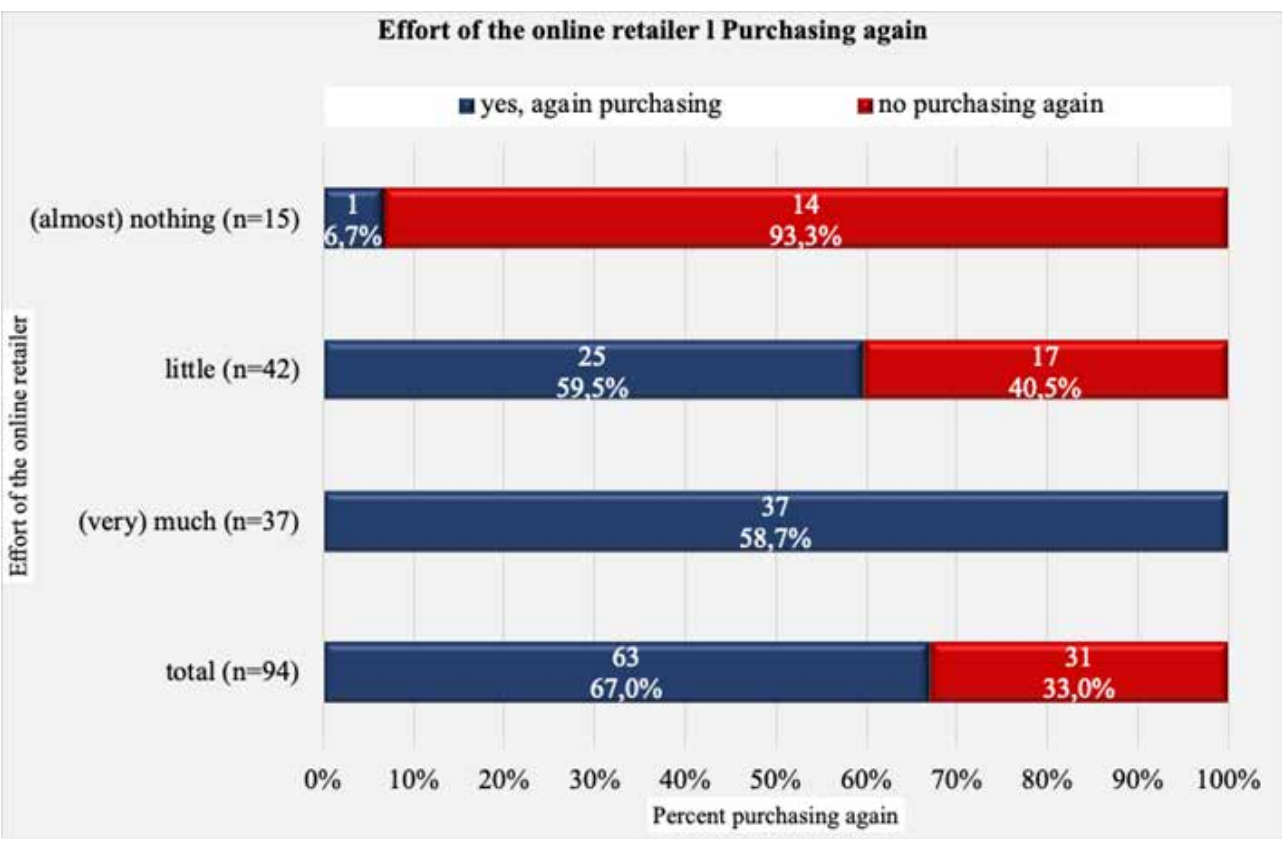

Figure 5. Effort of the online retailer

\section{DISCUSSION}

This review corroborates the previous findings suggesting that compensation has a beneficial influence on consumer loyalty and repurchase expectations (Smith et al., 1999). Bitner et al. (1990) noted that specialized cooperative companies that clarify that an assistance breakdown is remote might get a decent response from customers. In this investigation, clients regarded clarification as immaterial, and no significant outcomes were found.

There are several reasons for customer disappointment, including how service providers respond to their complaints (Spreng et al., 1995). According to Bitner et al. (1990), 42.9\% of dissatisfied consumers are due to the incompetence of service providers. However, companies can develop costeffective and intelligent models to solve problems and increase customer loyalty and sales (Blodgett et al., 1997).
Companies are less likely to heed customer protests (Conlon \& Murray, 1996), and management recovery is essential to maintaining a long-standing customer relationship (Smith et al., 1999). With this in mind, the following questions remain unanswered:

- What are the vital characteristics of a successful service recovery?

- What criteria do customers use to judge service recovery?

- How does good service recovery affect customer satisfaction and future behavior?

A company's response could restore customers' satisfaction to disappointment, or they might find it more challenging to switch to other brands and stores (Smith \& Bolton, 1998). Solid management support in all relevant areas is another critical success factor. The following are the important management implications. 


\section{Journal of Contemporary Management Issues}

First, management must create a system and culture that enables customer service and handling service failures. Employees who work in customer service are important members of a company's management team. Their goal is to ensure that the consumer leaves the conversation satisfied and with a satisfactory response to their concerns. However, when there are conflicting interests, this is not always easy.

Second, many people find dealing with complaints complicated. However, successful service recovery offers an excellent opportunity to increase customer loyalty and purchase intent. Therefore, complaints should be viewed as a positive challenge rather than a failure.

\section{CONCLUSION}

This study examined the effects of service recovery on university students in an Internet-based survey.

The theoretical contributions of this study are that online stores must equip and empower their employees to respond quickly and effectively to service failures. However, these policies can only be effectively enforced if service providers are sufficiently qualified and aware of the structure and procedures. In addition, web-based retailers and their employees should learn from administration disappointments to reduce the likelihood of future assistance disappointments, which can be more costly for online organizations.

Half of the participants emailed them or filled out an online form. However, $17 \%$ did not express their dissatisfaction, and a third of them did not do so because they thought it was pointless. The study found that about $75 \%$ of respondents who received a response from the company plan to shop at that online retailer again. A lack of response has a negative impact on shopper behavior. Customers who have received a response from an online retailer are more likely to buy from them again, which is one of the primary purposes of customer service.

About $90 \%$ of customers who have not received a response will not recommend the retailer to others. Therefore, understanding the importance of customer response is critical to service recovery and customer relationship management. In addition, online retail managers must recognize that offering no response to customers can negatively impact their business today and in the future. In contrast, companies that react are more likely to be recommended to others.

\section{REFERENCES}

1. Anzivino, N., \& Moliterno, C. (2020). Vitamins \& dietary supplements market trends - Overview. https://www. pwc.com/it/it/publications/assets/ docs/Vitamins-Dietary-SupplementsMarket-Overview.pdf.

2. Bitner, M. J., Booms, B. H., \& Tetreault, M. S. (1990). The service encounter: Diagnosing favourable and unfavourable incidents. Journal of Marketing, 54(1), 71.

3. Blodgett, J. G., Hill, D. J., \& Tax, S. S. (1997). The effects of distributive, procedural, and interactional justice on post complaint behaviour. Journal of Retailing, 73(2), 185-210.

4. Blom, A. G., Gathmann, C., \& Krieger, U. (2015). Setting up an online panel representative of the general population. Field Methods, 27(4), 391-408.

5. Chang, H. H., Lai, M., \& Hsu, C. (2012). Recovery of online service: Perceived justice and transaction 
frequency. Computers in Human Behaviour, 28(6), 2199-2208.

6. Daniells, S. (2015, September 23). College students more likely than general population to use dietary supplements, says survey. Nutraingredients. https://www.nutraingredients-usa.com/Article/2015/09/23/ College-students-more-likely-thangeneral-population-to-use-dietarysupplements-says-survey?utm_source=copyright\&amp;utm_medium $=$ OnSite\&amp;utm_campaign=copyright.

7. Forbes, L. P., Kelley, S. W., \& Hoffman, K. D. (2005). Typologies of e-commerce retail failures and recovery strategies. Journal of Services Marketing, 19(5), 280-292.

8. Goetzinger, L., Park, J. K., \& Widdows, R. (2006). E-customers' third party complaining and complimenting behaviour. International Journal of Service Industry Management, 17(2), 193-206.

9. Hart, C. W., Heskett, J. L., \& Sasser, W. E. (1990). The profitable art of service recovery. Harvard Business Review, 68(4), 148-156.

10. Komunda, M., \& Osarenkhoe, A. (2012). Remedy or cure for service failure? Business Process Management Journal, 18(1), 82-103.

11. Kuo, Y., \& Wu, C. (2012). Satisfaction and post-purchase intentions with service recovery of online shopping websites: Perspectives on perceived justice and emotions. International Journal of Information Management, 32(2), 127-138.

12. Larivière, B., Joosten, H., Malthouse, E. C., Birgelen, M. V., Aksoy, P., Kunz, W. H., \& Huang, M. (2013). Value fusion. Journal of Service Management, 24(3), 268-293.
13. Lin, C., \& Lekhawipat, W. (2014). Factors affecting online repurchase intention. Industrial Management \& Data Systems, 114(4), 597-611.

14. Mangold, W. G., \& Smith, K. T. (2012). Selling to millennials with online reviews. Business Horizons, 55(2), 141-153.

15. McCollough, M. A., Berry, L. L., \& Yadav, M. S. (2000). An empirical investigation of customer satisfaction after service failure and recovery. Journal of Service Research, 3(2), 121-137.

16. Ozturk, A. B., Bilgihan, A., Nusair, K., \& Okumus, F. (2016). What keeps the mobile hotel booking users loyal? Investigating the roles of self-efficacy, compatibility, perceived ease of use, and perceived convenience. International Journal of Information Management, 36(6), 1350-1359.

17. Sahu, P. K. (2016). Research methodology: A guide for researchers in agricultural science, social science and other related fields. Springer.

18. Smith, A. K., \& Bolton, R. N. (1998). An experimental investigation of customer reactions to service failure and recovery encounters. Journal of Service Research, 1(1), 65-81.

19. Smith, A. K., Bolten, R. N., \& Wagner, J. (1999). A model of customer satisfaction with service encounters involving failure and recovery. Journal of Marketing Research, 36(3), 356-372.

20. Spreng, R. A., Harrell, G. D., \& Mackoy, R. D. (1995). Service recovery: Impact on satisfaction and intentions. Journal of Services Marketing, 9(1), 15-23.

21. Toufaily, E., Souiden, N., \& Ladhari, R. (2013). Consumer trust toward retail websites: Comparison between 


\section{Journal of Contemporary Management Issues}

pure click and click-and-brick retailers. Journal of Retailing and Consumer Services, 20(6), 538-548.

22. Tripp, T. M., \& Grégoire, Y. (2011). When unhappy customers strike back on the Internet. MIT Sloan Management Review, 52(3), 37-44.

23. Uitz, T. O., \& Jancikova, E. (2021). Service Failures and How the
Perception of Justice Affects the Level of Satisfaction. International Journal of Economics and Business Administration, IX (1), 105-117.

24. Van Vaerenbergh, Y., Vermeir, I., \& Larivière, B. (2013). Service recovery's impact on customers next-inline. Managing Service Quality, 23(6), 495-512.

\section{PROBLEMI U PRUŽANJU USLUGA U E-KUPOVINI DODATAKA ZA PREHRANU}

Sažetak

\begin{abstract}
Ovaj rad analizira nezadovoljstvo kupaca i metode ispravljanja pogrešaka u pružanju usluga u e-kupovini sportske prehrane i dodataka prehrani. Prikupljanje podataka je obavljeno elektronički, što je rezultiralo uzorkom od 155 studenata preddiplomske razine, s osam institucija visokog obrazovanja u centralnoj $i$ istočnoj Europi. Podaci su analizirani uz pomoć MannWhitney $U$ i hi-kvadrat testa. Pronađena je pozitivna veza između odgovora e-maloprodavača
\end{abstract}

na probleme u pružanju usluge te lojalnosti $\mathrm{ku}$ paca. Nakon učinkovitog rješavanja problema, preko $41 \%$ ispitanika je osjećalo veću predanost e-maloprodavaču, uz približno $60 \%$ ispitanika, koji su željeli ponoviti kupovinu i preporučiti emaloprodavača drugim kupcima.

Ključne riječi: marketing, maloprodaja, problemi u pružanju usluga, marketing usluga 